\title{
SEXUAL HARASSMENT IN EDUCATION: IDENTIFYING THE ISSUE AND FINDING THE POSSIBLE SOLUTION
}

\author{
Muzaffar Syah Mallow \\ Associate Professor Dr., Faculty of Syariah \& Law, Universiti Sains Islam Malaysia (USIM), Bandar \\ Baru Nilai, Negeri Sembilan Darul Khusus, Malaysia, Email: muzaffarsyah.mallow@yahoo.com
}

\begin{abstract}
Sexual harassment in education is an unwelcome or unwanted behavior of a sexual nature that interferes with victim's ability to learn, study, work or participate in any school or university activities. Sexual harassment encompasses a range of behavior from mild annoyances to sexual assault and rape. Sexual harassment can fall under the category of quid pro quo or hostile working or learning harassment. Sexual harassment can occur verbally, non-verbally, written, visual, psychologically and physically. Victim and perpetrator of sexual harassment can be either gender and at it can happen to and committed by anyone. In school and university, sexual harassment can happen to student and it can also happen to the educator themselves. Same goes with the perpetrator of sexual harassment, the perpetrator can either be the educator themselves and it can also be the student. Very important to highlight, the effects of sexual harassment can be very devastating to the victim regardless of their gender and position. Victims of sexual harassment can suffer significant psychological effects, including anxiety, depression, headaches, sleep disorders, weight loss or gain, nausea, lowered self-esteem and sexual dysfunction. In addition, in the higher education setting, student victims of sexual harassment may feel pressured to drop a class and study entirely from school and university as well as experiencing physical and psychological distress. If the problem faced by the victim prolong there is also a concern that the victim might attempt to commit suicide. Overall, sexual harassment causes a tense and unproductive working and learning environment. As for the perpetrator, the consequences of sexual harassment can also be very serious to them and their family. The perpetrator life will be effected and his or her reputation will be tarnish forever. If the perpetrator is the educator in school or university, it can affect his or her job and face legal repercussion under the country existing laws. If the perpetrator is a student, depend on level of age he or she will be send to counselling, joining special courses or face legal consequence. It is very crucial for steps be taken to prevent sexual harassment from occurring in school and university. Everybody in the school and university should know about the issue and take measures to prevent sexual harassment at any cost. Sexual harassment issue cannot be handle solely by those in school and university alone. Parent, the government and society should work together to stop sexual harassment from happen in school and university. Early detection of sexual harassment need to be taken seriously and immediate assistance should be given to the victim of sexual harassment in school and university. Thus, it is the objective of this paper to further identify the issue of sexual harassment in school and university and finding possible solutions to address the issue of sexual harassment in school and university effectively.
\end{abstract}

Keywords: Sexual, harassment, school, university, solutions. 


\section{INTRODUCTION}

Sexual harassment is not something which unknown to anyone in today's world. All countries in the world have been exposed with such issue for the last many years including Malaysia. Sexual harassment is one type of harassment which can severely affect people life. It has become a very serious issue which need serious attention by everyone. Sexual harassment can happen in many different social settings like at the workplace, at home, in school and universities, religious places, at bus stop or taxi stand, and other locations. The perpetrators or harassers as well as the victims can be of any gender. (Sexual Harassment, US EEOC, 2021). Sexual harassment can also happen to Lesbian, Gay, Bisexual, and Transgender (LGBT) community. (LGBT Sexual Harassment, TUC, 2021). The effects of sexual harassment can be devastating especially to the victim. Their normal life will be effected. Among the effects of sexual harassment to victim includes suffering from stress and facing humiliation, fronting depression, anxiety, and panic attacks. Victim might also suffer sleeplessness, nightmares, feeling shame and guilt. Victim will face difficulty to concentrate and focusing with their daily activities. Victim will also suffer from headaches, fatigue, loss of motivation, stomach problems, eating disorders which eventually can lead to weight loss or gain. Victim might also becoming addicted to any highly addicted substances like alcohol, drugs and others. The victim will become demoralized, feel betrayed, violated, angry, and many more. If the problem prolong, it can effects their mental well-being and physical health as well like increased in blood pressure, loss of confidence or selfesteem, want to be in isolation, and others. The victim might loss trust in people, facing traumatic stress, post-traumatic stress disorder (PTSD), complex post-traumatic stress disorder, and even having suicidal thoughts or attempts, and committing suicide. (Sexual Harassment: Myths and Realities, 2021 and Gender Issues, 2021).

As mentioned earlier, sexual harassment can happen to anyone and it can also happen at any locations. The most common place where sexual harassment cases been reported is at the workplace. There have been plenty of complained and reported cases involving sexual harassment which occurred at workplace not only in Malaysia but around the world. (Can refer further to Wendy McElroy, 2004 and Catharine A. MacKinnon and Reva B. Siegel, 2004). However, it is important for us to note that sexual harassment can also happen in our educational institutions like schools and universities. Sexual harassment in education is an unwanted behavior of a sexual nature that interferes with the victim ability to learn, study, work or participate in school or university activities. Sexual harassment encompasses a range of behavior from mild annoyances to sexual assault and rape. (Dzeich, Billie Wright and Linda Weiner, 1990). If sexual harassment committed by the educator, it is often framed as "sex for grades" and has attracted media attention throughout the world, partly in connection with the \#MeToo movement. (Marika Malaea, 2019). The issue of sexual harassment in education has also been highlighted in Malaysia in recent years. In July 2020, one student from local university in the country had lodge a police report over what she claimed was inaction taken by the university authorities which she studied over the alleged sexual harassment of her by an associate professor in the university. The victim (student) has urged the police to investigate saying that there were no details of the internal probe conducted by the university into the incident which happen. (Wong Kai Hui, 2020). However, later the police have confirmed ending their investigation on the allegations. According the police, the police had investigated and referred the case to the Deputy Public Prosecutor (DPP) on August 13, and the DPP had stated No Further Action (NFA) because the suspect has already faced disciplinary action from the university. (Ramieza Wahid, 2020). Recently the country also has been exposed with an allegation made by a 17 year old student who exposed her school teacher who making a jokes about rape during physical and health education class at her school. Feeling uncomfortable, the student lodge a report to the police. The student also received rape threat from her colleague after exposing the issue to the public and as a result had to lodge another police report because of it. (Geraldine Tong, 2021). However, similar with the sexual harassment issue involving one local university mentioned earlier, the police has decided that No Further Action (NFA) will be taken in for school girl case as the police received a No Further Action (NFA) notice from the Deputy Public Prosecutor regarding the case. (Free Malaysia Today, August 5, 2021). Not only that, the accused teacher has decided to take legal action against the student for defamation. (Shahrin Aizat Noorshahrizam, 2021).

In May 2021, the country has been exposed with a figured that $80 \%$ of sexual harassment and bullying cases in educational institutes involved educators and school authorities. The Malaysian non - governmental organization (NGO) conducted a study where it collected and analysed 275 testimonials shared by survivors who approached them via social media and WhatsApp. It analysis showed that 125 cases involved period spot checks, 108 were bullying and 88 involved sexual harassment, adding that many survivors experienced more than one form of violation. It also said $91.6 \%$ of survivors were women and girls. Men and boys constituted 6.2\%. "A total of 108 survivors revealed their ages when they were sexually harassed/bullied. 
Among them, $99(91.6 \%)$ of them were children. The age subgroup of 13 to 15 years old, when students (especially girls) experience pubertal changes, was found to be the stage when sexual harassment and bullying were most prevalent among survivors," as the NGO said. It also added that predominant sites of sexual harassment and bullying were primary, secondary and boarding schools, having 51,58 and 55 cases respectively. It also said that violations also occurred in colleges, day care centres and school camps, though much fewer in the number of cases. Perpetrators were predominantly figures of authority. It also said that out of 311 perpetrators, 247 of them $(79.4 \%)$ were teachers, religious teachers and wardens. (Malaysia Daily News, 2021). In a recent analysis done by local NGO, All Women's Action Society (Awam) and Save the Schools MY (STS), a total of 770 testimonies of abuse was compiled from survivors and others. The 770 testimonies were compiled from April 26 to Aug 13, hoping that key government stakeholders would prioritise this issue. Out of the 1145 incidents of abuse, a total of 1495 period spot checks, sexual harassment, bullying and other violations were identified. "What our findings depict of the safety and wellbeing of our children in schools is grim and heart-rending," said Awam. It found that survivors in close to 25 per cent of all incidents experienced multiple violations while 23.9 per cent of incidents of abuse disclosed psychosocial consequences that affected survivors' mental health, school life, relationships and even livelihood. "There are also 17 formal diagnoses of mental health conditions, with anxiety and depression making up close to 75 per cent of them," Awam noted. Additionally, among 1037 survivors, almost 20 per cent (199) are below 18years-old; and these were those who had disclosed their age. Moreover, it was also found that secondary school students consist of the largest age group among all survivors, across all four major violation categories namely sexual harassment, period spot checks, bullying, and others. "Survivors are predominantly female across all four major violation categories. Violations of sexual harassment had the highest discrepancy in the prevalence of survivor by gender, whereby the number of violations involving female-only survivors is 16.6 times more than those involving male-only survivors," Awam added. In the respective violation categories of sexual harassment, period spot checks, and bullying, school authority figures comprise the largest or second-largest group of perpetrators. Among all school authority figures, teachers constitute the most common perpetrators in sexual harassment and bullying. (Shivani Supramani, 2021 and Keertan Ayamany, 2021).

It is deeply sad to see all these happen in a modern and educated society. All these incidents clearly show to us that people are still unaware about the seriousness of the issue pertaining to sexual harassment itself. More educational and awareness programs to the public including to educators and students in schools and universities about such issues. School and university management must make active engagement with relevant associations and non - governmental organizations (NGOs) in order to properly trained and teach all their educators and pupils in school and university about sexual harassment. At the same time, the country also need to strengthen the existing laws and enforcement to deal with such issue so that such issue can be deal more effectively.

\section{DEFINITION, CATEGORIES AND TYPES OF SEXUAL HARASSMENT}

Before we go further into the topic, it is very important for us to have a clear understanding over the definition of sexual harassment itself, its categories and the forms it might take. It is very difficult for us to locate the true meaning of the word sexual harassment. Up to today, there is single acceptable universal agreement on the definition of sexual harassment itself. However, based on many discussions as well as reference which being made to rules and regulations from many jurisdictions including in Malaysia pertaining to the matter, sexual harassment can be understood and define as any unwanted or unwelcome conduct that is sexual in nature, and may be committed physically, verbally, non-verbally, psychologically and/or visually, which may cause the person being harassed to feel humiliated, offended or threatened. (Can refer further to Ahmad Shamsul Abd. Aziz, 2005, p. 19 \& Catherine A. MacKinnon, 1979, pp. 25 - 47). To establish sexual harassment in terms of specific acts or behavior is highly difficult because the acts of sexual harassment is hard to be measure (Ashgar Ali Ali Mohamed, 2004, p. 1). Therefore, there is a need to look at the context, the surrounding circumstances which include the victims' upbringing, culture as well as religious sensitivities before any final decision is to be given on the allegation which been put forward. Every nation have their own way and interpretation on establishing the allegation of sexual harassment. What is really required here is that the act or conduct of the perpetrator must be offensive which would affect the state and mind of the victim and it must relate to sexual matter. The following are some cases in which the courts have held the conduct to amount to sexual harassment: Physically molesting staff by touching parts of their bodies, peeping into toilet, making suggestive comments as a reward for arranging transfer, promotion with increase in salary, suggestion of a lewd and sexual nature, soliciting clients for sexual favours, and others. With the coming of new communications technologies, sexual harassment at the workplace may also take place through phone, Short Message Service (SMS), Multimedia Messaging Service (MMS), Internet Electronic 
Mail (E-Mail), Facebook, Twitter, WhatsApp, Instagram or other medium. (Tengku Dato' Omar Tengku Bot \& Maimunah Aminuddin, 2000, pp. 35 - 47). In Malaysia, any detail reference towards the definition of sexual harassment can be refer to the Code of Practice on the Prevention and Eradication of Sexual Harassment in the Workplace (hereinafter referred to as "the Code"). The state - drafted Code was introduced by the Malaysian Ministry of Human Resources in August 17, 1999. (New Straits Times (Malaysia), 18 August, 1999). The aim of the Code is to ensure that sexual harassment at the workplace does not occur and, if it does occur, adequate procedures are available to deal with the problem and prevent its recurrent. The introduction of the Code has shown the seriousness on the part of the government in dealing with the issue of sexual harassment at the workplace in the country. Though the Code focus on the issue of sexual harassment at the workplace, the examples provided in it are highly relevant and can be connected to sexual harassment which happen in schools and universities. It is vital to note that schools and universities can be consider as part of working places.

According to the Code, sexual harassment at the workplace has been define as any unwanted conduct of a sexual nature having the effect of verbal (Paragraph 8 (i) of the Code give the examples of offensive or suggestive remarks, comments, jokes, jesting, kidding, sounds, and questioning); non-verbal (Paragraph 8 (ii) of the Code give the examples of leering or ogling with suggestive overtones, licking lips or holding or eating food provocatively, hand signal or sign language denoting sexual activity, and persistent flirting); visual (Paragraph 8 (iii) of the Code give the examples of showing pornographic materials, drawing sex based sketches or writing se based letters, and sexual exposure); psychological (Paragraph 8 (iii) of the Code give the examples of repeated unwanted social invitations, relentless proposals for dates or physical intimacy); and physical harassment (Paragraph 8 (iii) of the Code give the examples of inappropriate touching, patting, pinching, stroking, brushing up against the body, hugging, kissing, fondling, and sexual assault) that might, on reasonable grounds, be perceived by the recipient as placing a condition of a sexual nature on her or his employment (See paragraph 4 (i) of the Code) or as an offence or humiliation, or a threat to her or his well-being, but has no direct link to her or his employment (See paragraph 4 (ii) of the Code). From this definition, it is clear that the Code prohibits both quid pro quo and hostile working environment harassment which is unwanted and unwelcome to the recipient in the workplace. The unwanted nature of sexual harassment at the workplace distinguishes it from behaviour that is welcome and mutual. Sexual attention becomes sexual harassment if the behaviour is persisted in, although a single incident of harassment can constitute sexual harassment and/or the recipient has made it clear that the behaviour is considered offensive and/or the perpetrator should have known that the behaviour is regarded as unacceptable. The Code has also included an extensive definition of the work workplace. Paragraph 6 of the Code states that sexual harassment in the workplace includes any employment-related sexual harassment occurring outside the workplace as a result of employment responsibilities or employment relationship. Situations under which such employment-related sexual harassment may take place includes, but is not limited to: (i) at work-related social functions; (ii) in the course of work assignments outside the workplace; (iii) at work-related conferences or training sessions; (iv) during work-related travel; (v) over the phone; and (vi) through electronic media.

It must be highlighted clearly here that currently in Malaysia there is still no specific legislation the address the issue pertaining to sexual harassment. In absence of specific legislation to deal with the matter, the issue relating to sexual harassment has be consider under various types of existing legislations in the country which having their own weaknesses and limitation in addressing with this highly sensitive and complex issue. (Cecilia Ng, Zanariah Mohd Nor, \& Maria Chin Abdullah, 2003, p. 42). Among the legislations include the criminal legislation like the Penal Code [Act 574], the country labour laws like the Employment Act 1955 [Act 265], Industrial Relations Act 1967 [Act 177] and Occupational Safety \& Health Act 1994 [Act 514] as well administrative laws like the Code of Conduct of the Public Officers (Conduct and Discipline) Regulations 1993 and the government Circular Guidelines for Handling Sexual Harassment in the Workplace No. 5, 2018. (Can refer further to Siti Zaharah Jamaluddin, 2000, pp. 153 - 177, Sharifah Suhanah Syed Ahmad, 2012, pp. $179-196$, \& Ashgar Ali Ali Mohamed, 2014, pp. 35 - 74). For many years, victims of sexual harassment in the country can only get the offenders punished and they could never get any form of compensation. This however changed in 2016, with the Federal Court ruling in the case of Mohd Ridzwan bin Abdul Razak v Asmah bt $\mathrm{Hj}$ Mohd Nor [2016] 4 MLJ 282 where effectively for the first time Malaysia introduced the tort of sexual harassment into the Malaysian legal system. There have been many reported cases of sexual harassment involving pupils in the education sectors in the country which been reported. Most of the cases been investigate and charged under criminal law, namely the Penal Code [Act 574]. Reference can be made to the following cases Sallehudin Abdul Manaf v PP [2019] 1 LNS 582, Abdul Majid Ahmad v PP [2018] 1 LNS 1097, Yek Hock Soon v PP [2013] 8 CLJ 708, PP v Abdul Wahid Mohd Haneepa [2010] 1 LNS 1134, and Abdul Ghani Daud v PP [2005] 1 CLJ 120. 
Due to the sensitive and complex nature of sexual harassment, all the mentioned existing laws and rules we have in the country cannot address sexual harassment issue effectively. Instead of inserting sexual harassment matter under any existing laws or rules, it would be much better to have stand-alone law to regulate such issue. Due to this reason, in 2001, a number of NGOs has called for a stand-alone law on sexual harassment in the country. It is known as the Sexual Harassment Bill 2001. This proposed bill adequately addresses sexual harassment issue. The proposed bill covers occurrences of sexual harassment in the workplace and in circumstances where at least one party is working. It also covers harassment at sporting activities, educational institutions, and legislative bodies. If passed, the proposed bill will bring about significant changes as it addresses many fundamental points needed to cope with the sensitivity and complexity of sexual harassment cases whereby it will requires all employers to prevent sexual harassment by creation of in-house mechanisms to deal with the issue. It also provides victims of sexual harassment with timely and meaningful access to legal redress. The proposed bill also focus on the creations of special tribunal, procedure, remedies, counseling, and protection against retaliation and victimization for both victims and witness in sexual harassment cases. The proposed Sexual Harassment Bill was expected to be tabled in the Parliament at House of Representatives (Dewan Rakyat) on December 16, 2021. Deputy Women, Family, and Community Development Minister YB Datuk Siti Zailah Mohd Yusoff said the proposed Bill will be tabled at the Lower House after receiving the green light from the country Attorney-General's Chambers (AGC) and country Cabinet. The review of the proposed Bill needs to be done carefully to ensure it can fill the gaps of the existing laws, as well as on its implementation. (Nuradzimmah Daim and Nor Ain Mohamed Radhi, 2021).

\section{SEXUAL HARASSMENT IN EDUCATION}

As mentioned earlier, sexual harassment in education is any unwanted behavior of a sexual nature that interferes with victim ability to learn, study, work or participate in school or university activities. As also been stated earlier, sexual harassment encompasses a range of behavior from mild annoyances to sexual assault and rape. (Dzeich, Billie Wright and Linda Weiner, 1990). When we mentioned the issue pertaining to sexual harassment which happen in any institution of education whether at school level or university level, it is very important to note that the victim and the perpetrator to such offence can be anyone. For the many years, stories been highlighted in media which only portrayed the victim to such offence only consist of students and the perpetrator been portrayed of being an adult educator. As a result to these constant news, the public now has a misguided perception that sexual harassment which happen in any institution of education only involve the student victim and the adult educator perpetrator. As a result to these, some peoples started to see educator as a monster which need a constant watch from the authorities and students always been seen as innocent individual throughout the duration of their pupil status either in school or at the university. Important for the society to change their misguided perception towards such issue. The victim of might be the student and at the same time the victim might also be the teacher or an administrator working in the institution. Same goes with the perpetrator to such offence. The perpetrator might be the educator themselves like teacher in school or lecturer in a university. At the same time, the perpetrator might also be the student themselves. (Refer further to Clementine Ford, 2021 and Sarah Haque, 2021). According to the Malaysian Ministry of Education (MOE), until July 31, 2020, there around 10,220 schools in Malaysia with 7,780 primary schools and 2,440 secondary schools. (Statistic of schools, students and teachers, Malaysia, Ministry of Education (MOE), 2021). According to the Malaysian Ministry of Higher Education (MOHE), as to 2020, there are around 20 public universities in the country. Malaysia also home to many Private Higher Education Institution with University Status, Private Higher Education Institution with University Status (Branch Campus of Foreign University), Private Higher Education Institution with University College Status, and Private Higher Education Institution with College Status. (Higher Education Statistics, Malaysian Ministry of Higher Education (MOHE), 2021).

As to the categories and types of sexual harassment, this matter has already been explain earlier in this paper, as such focus now will only be given to the causes and effects of sexual harassment which happen in institution of education. It is very difficult to highlight any exact cause which give rise to the issue of sexual harassment in school and university. However, the main cause might be because of lack of understanding and knowledge about the issue of sexual harassment itself. It a well-known fact that sexual harassment is a very sensitive and complex issue which should be address seriously. People really need to understand the meaning of sexual harassment, categories and forms it might take as well as the effects it bring to the victim, the perpetrator and to everyone. Lack of understanding and knowledge about the issue of sexual harassment will certainly give rise to sexual harassment problem not only in any institution of education like school and university but also anywhere. Sexual harassment also might occur because lack of seriousness and supervision on part of the school or university management to tackle with the issue. Often, schools and 
universities have been over burden with other matters which affect their ability to address with this issue more effectively. Lack of seriousness to tackle with this issue will certainly encourage people to commit such offence. Outdated or having ineffective standard operating procedures (SOPs), rules and regulations might also become the cause to sexual harassment in schools and universities. Complex and sensitive issue like sexual harassment must be address cautiously with suitable SOPs, rules and regulations. With the advancement of technologies like internet and smart phone where it might become new platform to sexual harassment problem will require new set of SOPs, rules and regulations to address with the problem more effectively. (Can refer further to Safeguarding Resource and Support Hub, 2021).

The effects of sexual harassment can be very severe not only to the victim but also to the perpetrator and surrounding environment. As explained earlier in this paper, the effect of sexual harassment particularly to the victim can be detrimental to his or her mental and psychological well-being like possibility of having nervous breakdown, difficulty in concentrating with their daily activities or sleeping, feeling insecure, feeling ashamed to themselves, want to be isolated from family, friends and public, feeling tense and pressure, attempting suicide and even committing suicide. (Sexual Harassment: Myths and Realities, 2021 and Gender Issues, 2021). If the victim happen to be students in school or university, the common effect would be the inability for them to focus with their study and learning process. If the victim happen to be the educator or administrator, they too will face difficult to perform their jobs and duties. The impact of sexual harassment also will severely effects the life of the perpetrator where the perpetrator will face with many questions from the authorities during the investigation process, facing possible legal actions when the issue been brought to court and facing with harsh punishment. The conviction will also tarnish the perpetrator name and reputation forever. The perpetrator will face with many problems living in the society after having mark of harasser. Whatever been done by the perpetrator will also impact the life his or her family. Sexual harassment which happen in school or university will also bring bad name and reputation to the place especially when the place fail to take the issue seriously. Failure to take early steps to prevent sexual harassment or failure to investigate any allegation of sexual harassment which happen in the place will bring more negative impact to these places. If the issue prolong, everybody will feel unsafe and feeling demoralize to go to school and university. If we unable to prevent sexual harassment at our educational institutions, it will be very hard for us to address this issue in our society, thus sexual harassment will become a common problem which hard to be control and prevented. (Can refer further to Consequences of Sexual Harassment, 2021 \& Karun Bhandanker, 2021).

\section{POSSIBLE SOLUTIONS}

Prevention is much better than cure. Early steps must be taken to address the issue of sexual harassment in education whether at schools or at universities. Steps taken should be effective to tackle with problems. We cannot use the unchanged SOPs, rules and regulations which have been produced many years ago to deal with the problem. There are many arising issues which need to be taken into consideration in addressing the issue. Though the Ministry of Education (MOE) has provide a guidelines way back 2011 for schools in our country to deal with the issue of sexual harassment, it should be re-look, re-examine, and re-implement again so that it is effective to deal with the issue. Same goes to universities. Universities management should create a more comprehensive sexual harassment prevention policy in the campus. Having a policy is one thin but taking action is another thing. Both having policy and taking action to deal with the issue of sexual harassment must come together. Any complain or report pertaining to sexual harassment must be taken seriously and be investigated. The victim deserve to know the outcome of the investigation immediately. Schools and university management must never hide the problem in order to protect their own reputation. It's better to tell the truth than living in life full of lies and deceptions. Both schools and universities management should engaged actively with any local NGOs in the country in order to prepare any policy relating to sexual harassment preventions. There are many local NGOs in the country which have done many researches on the issue of sexual harassment and prepared suitable mechanisms to deal with the problem. They should also actively cooperate with the local NGOs in order to train their educator properly about the issue of sexual harassment. Sexual harassment issue cannot be learn simply from a book or through internet because it is a very complex and sensitive issue.

Important also to remember, education providers in the country have a legal duty to take steps to prevent and respond to sexual harassment issue. They must make sure they keep poison-free environments that respect human rights and values. From a human rights perspective, it is not acceptable to ignore sexual harassment, whether or not someone has formally complained. When deciding if an education provider has met its duty to respond to such claim, tribunals or courts must take the following into consideration: The procedures in place at the time to deal with sexual harassment, how quickly the organization responded to such complain, how seriously the complaint was treated, the resources made available to deal with such 
complaint, does the organization provide a healthy and safe environment for the person who complained, and how well the person who complained was told about the action taken. Educators can prevent many cases of sexual harassment by having a clear, comprehensive anti-sexual harassment policy in place. In cases of alleged sexual harassment, the policy will alert all parties to their rights, roles and responsibilities. Policies must clearly set out how the sexual harassment will be dealt with promptly and efficiently. An effective sexual harassment policy can limit harm and reduce liability. It also promotes the equity and diversity goals of educational institutions. Education providers should monitor their environments regularly to make sure they are free of sexually harassing behaviors. Taking steps to keep a poison-free environment will help make sure that sexual harassment does not take root, and does not have a chance to grow. While waiting for the government to consider creating a specific sexual harassment prevention law, every level of government ministries and enforcement authorities in the country must take efforts to improve the existing SOPs, rules and regulations to address the issue of sexual harassment effectively. Every government agencies in the country must exercise their power honestly and professionally and this includes the Attorney - General (AG). This matter can be seen in the case of PP $\vee$ Zainuddin \& Anor [1986] 2 MLJ 100 where it been stated that "The law and Constitution in giving the Attorney - General an exclusive power respecting direction and control over criminal matters expect him to exercise it honestly and professionally. The law gives him a complete trust in that the exercise of this power is his and his alone and that his decision is not open to any judicial review. If he is a Minister of the Government he is answerable to Parliament and to his cabinet colleagues, and if he is not, the Government will answer for him in Parliament, whilst he himself will be answerable to the Government, and if he is a civil servant he will be answerable also to the Judicial and Legal Service Commission, though anomalously he is a member of it. Members of the public expect that he exercises his power bona fide and professionally in that when he prefers a charge against an individual he does so because public interest demands that prosecution should be initiated and when he refrains from charging an individual or discontinues a prosecution already initiated he also acts upon the dictate of public interest". All sexual offences cases is a very sensitive issue. Decision not to proceed with any criminal charges should be further clarify and properly inform to the public including to the victim in order to avoid misperception to the public and to avoid anyone from feeling demoralized or discouraged from lodging sexual harassment complaint in the future.

\section{REFERENCE LIST}

Ahmad Shamsul Abd. Aziz. (2005). Undang - Undang Gangguan Seksual Di Malaysia. Pahang: PTS Publications \& Distributions Sdn. Bhd.

Ashgar Ali Ali Mohamed. "Sexual Harassment in the Workplace: The Law and Practice in Malaysia". [2004] 1 Malayan Law Journal (MLJ) (Malaysia) 1.

Ashgar Ali Ali Mohamed. (2014). Dismissal from Employment and the Remedies. Second Edition. Malaysia: LexisNexis.

Cecilia Ng, Zanariah Mohd Nor, \& Maria Chin Abdullah. (2003). A Pioneering Step: Sexual Harassment \& The Code of Practice in Malaysia. Selangor: Vinlin Press Sdn. Bhd.

Clementine Ford. (March 30 - April 9, 2021). Students sexually harassing teachers. Saturday Day.https://www.thesaturdaypaper.com.au/news/education/2019/03/30/students-sexually-harassingteachers/15538644007918\#hrd. Retrieved on December 10, 2021.

Consequences of Sexual Harassment. (2021). https://www.ramapo.edu/titleix/sexual-harassmentresources/consequences-sexual-harassment/. Retrieved on December 10, 2021.

Dzeich, Billie Wright and Linda Weiner. (1990). The Lecherous Professor: Sexual Harassment on Campus, University of Illinois Press.

Free Malaysia Today. (August 5, 2021). No further action against teacher over alleged rape jokes. https://www.freemalaysiatoday.com/category/nation/2021/08/05/no-further-action-against-teacherover-alleged-rape-jokes/. Retrieved on December 9, 2021.

Gender Issues, ILO Encyclopedia of Occupational Health and Safety. International Labour Organization. 2: 34.1-34.77. 23 May 2002. https://web.archive.org/web/20081220123857/http://www.ilo.org/public/english/protection/safework/g 
ender/encyclo/psy14ae.htm. Retrieved on December 9, 2021.

Geraldine Tong. (April 27, 2021). Teen who exposed teacher's 'rape jokes': I'm doing this for every student, not just me. Malaysia News. https://malaysia.news.yahoo.com/teen-exposed-teachers-rape-jokes020500042.html. Retrieved on December 9, 2021.

Higher Education Statistics, Malaysian Ministry of Higher Education (MOHE). (2020). https://www.mohe.gov.my/carian?q=statistik+pendidikan+tinggi\&option=com_finder\&ltemid=101. Retrieved on December 10, 2021.

Karun Bhandanker. (November 14, 2017). The Effects of Sexual Harassment on Teens. https://theswaddle.com/effects-of-sexual-harassment-on-teens/. Retrieved on December 10, 2021.

Keertan Ayamany. (December 1, 2021). How safe are our schools? Study notes over 1,000 testimonies so far from sexual harassment to rape and bullying. https://www.malaymail.com/news/malaysia/2021/12/01/how-safe-are-our-schools-study-notes-over1000-testimonies-so-far-from-sexu/2025175. Retrieved on December 10, 2021.

LGBT Sexual Harassment. Trades Union Congress. https://www.tuc.org.uk/campaigns/lgbt-sexualharassment. Retrieved on December 9, 2021.

MacKinnon. Catherine A. (1979). Sexual Harassment of Working Women: A Case of Sex Discrimination. New Haven and London: Yale University Press.

MacKinnon, Catharine A.; Siegel, Reva B. (2004). Directions in Sexual Harassment Law. Yale University. p. 8

Malaysia Daily News. (May 18, 2021). NGO: Study showed $80 \%$ of sexual harassment, bullying cases involved teachers, school authorities. https://malaysiadailynews.com/ngo-study-showed-80-ofsexual-harassment-bullying-cases-involved-teachers-school-authorities/. Retrieved on December 9 , 2021.

Marika Malaea On 10/8/19 at 8:15 PM (2019-10-08). "\#SexForGrades documentary trending worldwide, reveals sexual harassment university scandal". Newsweek. https://www.newsweek.com/call-actionresponse-undercover-sex-grades-university-scandal-1463982. Retrieved on December 9, 2021.

McElroy, Wendy (October 27, 2004). "The Sad Evolution of Sexual Harassment". iFeminists.com. http://www.wendymcelroy.com/ifeminists/2004/1027.html. Retrieved on December 9, 2021.

Nuradzimmah Daim and Nor Ain Mohamed Radhi. (November 15, 2021). Sexual Harassment Bill expected to be tabled by Dec 16. New Straits Times.

https://www.nst.com.my/news/nation/2021/11/745557/sexual-harassment-bill-expected-be-tableddec-16. Retrieved on December 9, 2021.

Ramieza Wahid. (August 27, 2020). UM lecturer sexual assault claim: Police confirm no further action. Malaysiakini. https://www.malaysiakini.com/news/540379. Retrieved on December 9, 2021.

Safeguarding Resource and Support Hub. (January, 2021). Root Causes of Sexual Exploitation, Abuse and Sexual Harassment (SEAH). https://safeguardingsupporthub.org/sites/default/files/2021 03/SDD_RSH_Root_Causes_plain_languge\%20_FINAL.pdf. Retrieved on December 10, 2021.

Sarah Haque. (October 21, 2020). When Students Sexually Harass Teachers. https://www.vice.com/en/article/4adgn3/when-students-sexually-harass-teachers. Retrieved on December 10, 2021.

Sexual harassment. U.S. Equal Employment Opportunity Commission. https://www.eeoc.gov/sexualharassment. Retrieved on December 9, 2021.

Sexual Harassment: Myths and Realities. Journal of the American Psychological Association. https://web.archive.org/web/20080516085341/http://www.uoregon.edu/ counsel/harass.htm. Retrieved on December 9, 2021.

Shahrin Aizat Noorshahrizam. (November 30, 2021). Former physical education teacher accused of rape jokes sues student Ain for alleged defamation. https://www.malaymail.com/news/malaysia/2021/11/30/former-physical-education-teacher-accusedof-rape-jokes-sues-student-ain-fo/2024878. Retrieved on December 9, 2021.

Sharifah Suhanah Syed Ahmad. (2012). Industrial Relations Law in Malaysia: Cases \& Materials. Kuala 
Lumpur: University of Malaya Press.

Shivani Supramani. (November 30, 2021). Awam: Testimonies from abuse survivors reveal a bleak picture. The Sun Daily. https://www.thesundaily.my/home/awam-testimonies-from-abuse-survivors-reveal-ableak-picture-BE8611355. Retrieved on December 9, 2021.

Siti Zaharah Jamaluddin. (2000). Pengenalan Undang - Undang Perhubungan Perusahaan di Malaysia. Kuala Lumpur: Penerbit Universiti Malaya.

Statistic of schools, students and teachers, Malaysia, Ministry of Education (MOE). (July 31, 2020). https://www.moe.gov.my/en/statistik-menu/statistik-bilangan-sekolah-murid-guru. Retrieved on December 10, 2021.

Tengku Dato Omar Tengku Bot \& Maimunah Aminuddin. (2000). A guide to the Malaysian Code of Practice on Sexual Harassment in the Workplace. Kuala Lumpur: Leeds Publications.

Wong Kai Hui. (July 15, 2020). UM student lodges report over sexual harassment involving associate professor. Malaysiakini. https://www.malaysiakini.com/news/534580. Retrieved on December 9, 2021. 